\title{
Liver Alveolar Echinococcosis Metastasized to the Breast
}

\author{
Yavuz Albayrak $^{\mathrm{a}} \quad$ Ahmet Kargi $^{\mathrm{b}} \quad$ Ayse Albayrak ${ }^{\mathrm{c}} \quad$ Ibrahim Gelincik $^{\mathrm{d}} \quad$ Yavuz B. Cakir $^{\mathrm{e}}$ \\ aDepartment of General Surgery and Burn Unit, \\ bepartment of General Surgery, \\ 'Department of Clinical Bacteriology and Infectious Diseases, \\ dDepartment of Pathology, \\ eDepartment of Radiology, Erzurum Region Education and Research Hospital, Erzurum, Turkey
}

\section{Keywords}

Alveolar echinococcosis · Breast · Liver - Albendazole

\section{Summary}

Background: Alveolar echinococcosis $(A E)$ is a potentially fatal and chronically progressive infestation produced by the multivesicular metacestode of Echinococcus multilocularis, which most commonly affects the liver, lungs, and brain. Case Report: We present a case of $A E$ in which an alveolar cyst, as a result of exophytic growth, adhered to intra-abdominal and pelvic organs and metastasized to the breast. Exploration showed that the exophytic cyst in the liver filled the entire abdominal cavity, reaching to the uterus and bladder, and was adherent to the neighboring tissues and organs. This cystic lesion was totally excised, as was the $7 \times 6 \mathrm{~cm}$ cystic lesion in the right breast. Conclusions: The liver is the most common site for echinococcal cysts of the pastoral strains ( $>65 \%$ ), followed by the lungs $(25 \%)$; the cyst is seen less frequently in the spleen, kidneys, heart, bone, and central nervous system. AE must be considered in areas where liver cysts are endemic and in the presence of a liver cyst, and the organs where a metastasis is possible must be thoroughly investigated. Furthermore, in these areas, when cystic disorders of the breast are present, AE should not be discounted among possible definitive diagnoses.

\author{
Schlüsselwörter \\ Alveoläre Echinokokkose · Brust · Leber · Albendazol
}

\section{Zusammenfassung}

Hintergrund: Die alveoläre Echinokokkose ( $A E$ ) ist ein potenziell tödlicher und chronisch progressiver Befall durch den multivesikulären Metazestoden von Echinococcus multilocularis. AE betrifft am häufigsten die Leber, die Lunge und das Gehirn. Fallbericht: Wir berichten von einem Fall von $A E$, bei dem eine alveoläre Zyste infolge exophytischen Wachstums mit Organen der Bauch- und Beckenhöhle verwachsen und in die Brust metastasiert war. Die Untersuchung ergab, dass die exophytische Zyste in der Leber die gesamte Bauchhöhle bis hin zur Gebärmutter und Blase ausfüllte und mit benachbarten Geweben und Organen verwachsen war. Diese sowie eine zystische Läsion in der rechten Brust $(7 \times 6 \mathrm{~cm})$ wurden komplett operativ entfernt. Schlussfolgerungen: Echinokokkus-Zysten der pastoralen Form werden am häufigsten in der Leber angetroffen $(>65 \%)$, gefolgt von der Lunge (25\%). Weniger häufig betroffen sind die Milz, die Nieren, das Herz, die Knochen und das Zentralnervensystem. In Gebieten, wo Leberzysten endemisch sind und bei Vorliegen einer Leberzyste, sollte $A E$ in Erwägung gezogen weren. Organe, die von einer Metastasierung betroffen sein könnten, müssen gründlich untersucht werden. Außerdem sollte in diesen Gebieten bei Vorliegen einer zystischen Brusterkrankung $A E$ in die Differentialdiagnose einbezogen werden.

\section{KARGER \\ Fax +497614520714 \\ Information@Karger.de}

www.karger.com (c) 2011 S. Karger GmbH, Freiburg

$1661-3791 / 11 / 0064-0289 \$ 38.00 / 0$

Accessible online at:

www.karger.com/brc
Dr. Yavuz Albayrak

Department of General Surgery and Burn Unit

Erzurum Region Education and Research Hospital

25040 Erzurum, Turkey

Tel. +90 442 2325-561, Fax -090

yavuzalbayrakdr@gmail.com 

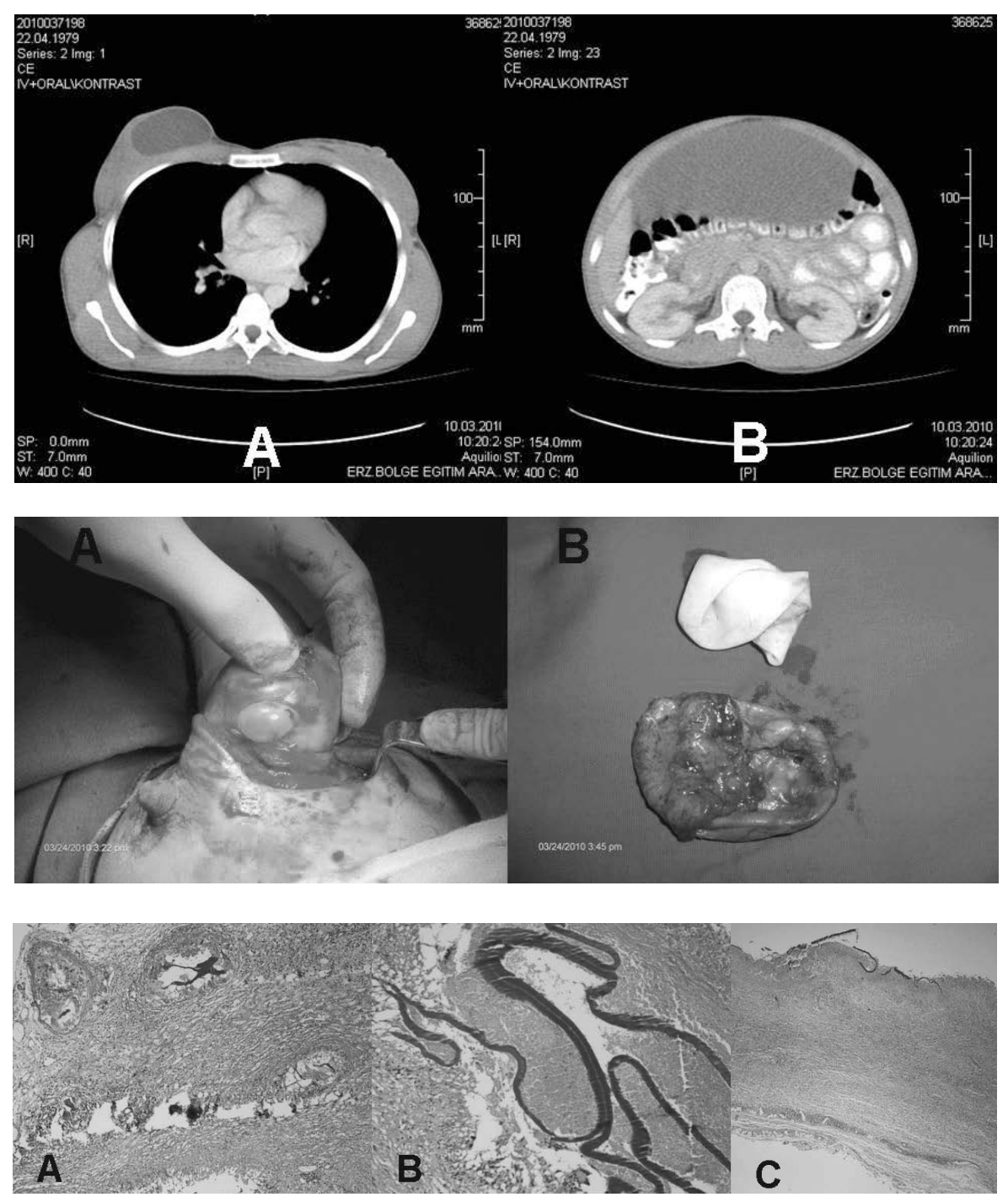

Fig. 1. A Computed tomography (CT) image of the cyst in the breast; $\mathbf{B}$ CT image of the exophytic alveolar echinococcosis cyst of the liver in the intra-abdominal region.
Fig. 2. A Cystic lesion and cuticular membrane in the breast; $\mathbf{B}$ postoperative excised cystic lesion in the breast.

Fig. 3. A Echinococcus alveolaris cysts showing granulomatous reaction inside the peritonium (PAS $\times 100)$; B laminary membrane positively dyed with PAS dye, with the middle section in necrotic granulomatous reaction $(\mathrm{PAS} \times 200)$; C cystic structures surrounded by laminary membrane inside the breast $(\mathrm{PAS} \times 40)$.

\section{Introduction}

Alveolar echinococcosis (AE) results from infection by the metacestode (larval) form of Echinococcus multilocularis, E. alveolaris, which most commonly affects the liver, lungs, and brain $[1,2]$. Human AE, a potentially fatal and chronically progressive parasitic infection, is characterized by a long asymptomatic period during which an invasive tumor-like lesion develops [1-3]. Early diagnosis of AE is very difficult because of the long latent or asymptomatic period which may be as long as 20 years [3]. We present a case of AE in which exophytic growth of an alveolar cyst led to its adhesion to the intra-abdominal and pelvic organs and also to metastasis to the breast. This is the first case of AE metastasis to the breast to be reported in the literature.

\section{Case Report}

A 31-year-old female patient presented at our clinic with complaints of pain and bloating in the abdomen and a swelling in the right breast that had been consistent for the past 2 years. The laboratory findings of the patient were normal. Physical examination of the patient revealed fluctuating masses that could be palpated in the abdomen and in the right breast. Tomography of the patient showed an image of a cystic lesion in the right breast, as well as an abdominal cystic lesion that initiated in the epigastric area. The abdominal lesion extended to the pelvis and pushed the intestinal loops located in the anterior towards the posterior (figs. 1 A, B). Exploration showed an exophytic cyst in the liver that filled the entire abdominal cavity, extending to the uterus and bladder, and was adherent to the neighboring tissues and organs. This cystic lesion was totally excised, as was the $7 \times 6 \mathrm{~cm}$ cystic lesion in the right breast (figs. $2 \mathrm{~A}, \mathrm{~B}$ ). Histopathological investigation with PAS dye revealed E. alveolaris cysts exhibiting granulomatous reaction and the laminary membranes paving these cysts (fig. 3 A). A dark positive dye reaction of the laminary membranes with PAS stain made them more conspicuous (fig. 3 B). Cross sections also showed focal calcifications and marked fibrosis, and in addition, cystic structures surrounded by laminary membrane inside the breast (fig. $3 \mathrm{C}$ ). In the postoperative period, the patient was started on albendazole $10 \mathrm{mg} / \mathrm{kg} /$ day and discharged. 


\section{Discussion}

AE is a potentially fatal and chronically progressive infestation produced by the multivesicular metacestode of $E$. multilocularis. A characteristic feature of this infection is its exogenous, tumor-like, multivesicular, infiltrating structure which consists of numerous small vesicles embedded in a stroma of connective tissue [1-3]. Although $\mathrm{AE}$ is a rare helminthic zoonosis with incidence rates $>0.1$ per 100,000, human AE may be considered a worldwide public health problem due to its widespread endemicity. Both E. granulosus and E. multilocularis are known to be endemic in Turkey, but little relevant data have been collected. Whereas cystic echinococcosis (CE) is encountered throughout Turkey, AE has only been observed in the cold, mountainous areas of the Eastern Anatolia region of Turkey, where our clinic is located [2, 4]. In a study conducted in our region, Polat et al. [5] reported 40 cases between the years 1987 and 2000 in Erzurum.

The liver is the most common site for echinococcal cysts of pastoral strains $(>65 \%)$, followed by the lungs $(25 \%)$. Cysts are encountered less frequently in the spleen, kidneys, heart, bone, and central nervous system [2]. In our case, an AE lesion adhered to intra-abdominal and pelvic organs and metastasized to the breast. We believe that the spread from the liver to the breast in our case was hematogenous. The available literature contains no reports of breast metastasis in patients with liver echinococcus, making our case the first such report.

Computed tomography (CT), magnetic resonance imaging, and ultrasonography of $\mathrm{AE}$ appear to be the most useful methods of diagnostic imaging. However, ultrasonography is the screening method of choice for the classification of cysts.
The CT appearance of the liver following AE infection consists of heterogeneous geographic and infiltrating lesions with irregular margins [6]. The lesions usually present as low density masses and do not demonstrate contrast enhancement. Contrary to the involvement of the liver, in the brain and lung, involvements emerge as several cystic or semisolid cysts. In our case, an image arising from the liver infiltrated a large part of the abdomen and emerged at the breast as a single cyst consistent with AE.

The treatment of an alveolar hydatid cyst consists of surgical extraction of the parasite, followed by chemotherapy. Surgery is the treatment of choice if the parasitic lesions are completely resectable, because it can cure the patient, whereas available drugs act only as parasitostatics in humans [7]. Chemotherapy must be instituted and maintained for at least 6 months. Albendazole is more efficacious than mebendazole, and can render $94 \%$ of the cysts nonviable after 3 months. Albendazole, at $10-15 \mathrm{mg} / \mathrm{kg} / \mathrm{day}$, is the drug of choice for human $\mathrm{AE}$, although it is primarily parasitostatic rather than curative [1-3].

AE must be considered in areas where liver cysts are endemic. In addition, in the presence of a liver cyst, the organs where metastasis is possible must be thoroughly investigated. Furthermore, in regions where AE is common, when cystic disorders of the breast are present, AE should not be discounted among possible definitive diagnoses.

\section{Disclosure Statement}

The authors declare that they have no competing interests. All authors declared that there was no sponsorship or funding arrangements relating to this study.

\section{References}

1 McManus DP, Zhang W, Li J, Bartley PB: Echinococcosis. Lancet 2003;362:1295-1304.

2 Moro P, Schantz PM: Echinococcosis: a review. In J Infect Dis 2009;13:125-133.
3 Pawlowski ZS, Eckert J, Vuitton D, et al.: Echinococcosis in humans: clinical aspects, diagnosis and treatment; in Eckert J, Gemmell MA, Meslin FX, Pawlowski Z (eds): WHO/OIE Manual on Echinococcosis in Humans and Animals: A Public Health Problem of Global Concern. Paris, World Organization for Animal Health and World Health Organisation, 2001, pp. 47-59.

4 Altintas N: Cystic and alveolar echinococcosis in Turkey. Ann Trop Med Parasitol 1998;92:637-642.
5 Polat KY, Balik AA, Çelebi F: Hepatic alveolar echinococcosis: clinical report from an endemic region. Can J Surg 2002;45:415-419.

6 Tüzün M, Hekimoğlu B: Pictorial essay. Various locations of cystic and alveolar hydatid disease: CT appearances. J Comput Assist Tomogr 2001;25:8187.

7 Buttenschoen K, Kern P, Reuter S, Barth TF: Hepatic infestation of Echinococcus multilocularis with extension to regional lymph nodes. Langenbecks Arch Surg 2009;394:699-704. 